\title{
INFLUENCE OF TECHNOLOGY ACCEPTANCE MODEL (TAM) ON CUSTOMER ADOPTION OF E-BANKING PRACTICE IN LAGOS STATE
}

\author{
Patrick Ladipo, 0000-0003-0420-9760, \\ Bolajoko Dixon-Ogbechi, 0000-0002-7606-1761, \\ Nnenna Enyinnaya, 0000-0002-38154844, \\ Olushola Akeke*, 0000-0003-2877-4801 \\ University of Lagos, University Road, Akoka, Yaba, Lagos, Nigeria \\ "Corresponding author: Olushola Akeke, solomonyz4real@yahoo.com
}

Received: 07.16.2021

Accepted: 08.27.2021

\begin{abstract}
This study was put together to examine the influence of TAM (Technology Acceptance Model) extension model on customer adoption of e-banking practice in Lagos state. Furthermore, to capture the extended model four (4) elements of innovation characteristics namely innovation relative advantage, innovation complexity, innovation compatibility and innovation information were added into original TAM model to determine their relationship with customer adoption. The study utilized descriptive research design and collected data through cross-sectional survey method. Validated questionnaires of four hundred copies were given to the needed respondents and the data collected were analyzed using both descriptive and inferential statistical tools. Results revealed a substantial relationship between the dimensions of TAM extension model and customer adoption. The study recommends that an innovation will do very well if the innovation is made to capture all the variables investigated in this study to ensure rapid diffusion/adoption of the innovation for the whole process to be successful.
\end{abstract}

Keywords: innovation relative advantage, innovation complexity, innovation compatibility, innovation information, customer adoption.

Rezumat. Acest studiu a fost realizat pentru a examina influența modelului de extensie TAM (Modelul de acceptare a tehnologiei) asupra adoptării de către clienți a practicii de e-banking în statul Lagos. În plus, pentru a surprinde modelul extins, au fost adăugate patru (4) elemente ale caracteristicilor inovației, respectiv: avantajul relativ al inovației, complexitatea inovației, compatibilitatea inovației și informațiile despre inovație în modelul original TAM pentru a determina relația lor cu adoptarea clienților. Studiul a utilizat un proiect de cercetare descriptivă și a colectat date prin metoda de cercetare transversală. Chestionarele validate de patru sute de exemplare au fost date respondenților necesari, iar datele colectate au fost analizate folosind atât instrumente statistice descriptive, cât și inferențiale. Rezultatele au relevat o relație substanțială între dimensiunile modelului de extensie TAM și adoptarea clienților. Studiul recomandă: pentru ca o inovație să funcționeze foarte bine, aceasta trebuie concepută prin a surprinde toate variabilele. De asemenea, este necesar de a asigura difuzarea / adoptarea rapidă a inovației pentru ca întregul proces să aibă succes. 
Cuvinte cheie: avantaj relativ al inovației, complexitatea inovației, compatibilitatea inovației, informații despre inovație, adaptarea clienților.

\subsection{Introduction}

Not long ago, immense shift has been encountered in the global economy which was facilitated by the introduction of information and communication technology [1]. The expansion of this information and communication technology has motivated the service sector especially the banking industry which is one of the key economic sectors to build up a modern service delivery known as e-banking service. Banks now capitalized on same impressively to match up with worldwide standard in several choices of enhanced e-banking service delivery and telecommunication networks [2, 3]. E-banking according to [4] suggest the supply of product and services of banks via electronic networks. Through the e-banking service, banks can shorten their processing periods; enhance business transaction adjustment, speed improvement and reduce cost with regard to physical serving of customer personally [5]. Despite the above-mentioned benefits of e-banking service, the overall accomplishment is determined by the extent to which prospective customers adopt it [6].

Understanding the adoption of e-banking service by customers is so crucial, that is why [7] noted that customer's adoption and usage continuation of these e-networks lead to total accomplishment of the innovation. As emphasized by [8], the adoption of a new technology is also the customer's decision making of utilizing the technology fully. Customers make adoption decision through the evaluation of information about the product/service characteristics [9]. Past researchers such [10] together with Rogers [8] also agreed that customer's insight to new products/services (innovation) characteristics is influenced by their adoption process and different innovation implementation. Conversely, innovation characteristics and innovation adoption studies have suggested the best consistent constructs e.g. complexity, relative advantage and compatibility [10]; relative advantage, trialability, ease of use, image, result demonstrability, voluntariness, visibility and compatibility [11]; compatibility, complexity, relative advantage, observability and trialability [8]; and innovation information (communicability, trialability and observability), compatibility (personal and social compatibility, social advantage, volition), relative advantage (relative advantage by attribute, economic advantage, customizability, product performance), risk and complexity (complexity in use and in-design, category risk, discontinuity) [9]. Hence, it is of significance to recognise these innovation attributes that critically encourage the personality's choice of acceptance of any innovation [12].

Consequently, present-day researchers on the subject of adoption of e-banking practice have brought forth numerous challenging models. [13] Found that the need for these established models were to investigate the new technologies adoption by customer. One of the models frequently employed is the Technology Acceptance Model (TAM) which was advanced by [14], adapted from the Theory Reasoned Action (TRA) and theorized with constructs like perceived usefulness and perceived ease of use as factors that discover the adoption of a technology by customers [1], [15]. Added that TAM model aided researchers to differentiate the reason behind adoption or rejection of a specific technology and boost appropriate steps by clarification of customer's expectation. However, as argued by [16] that despite the fact that TAM model results have displayed effectiveness but the potential and effectiveness of its utilization in the intentional adoption assessment of certain electronic services by customer are not effective. Other researchers criticised TAM model based on 
negligence of perceived usefulness contributing factor, inadequacy of clarification of weakness $[5,17,18]$ extended TAM model by adding diverse constructs. Thus, it is essential to develop an extended TAM model and framework that will be suitable to explain the customer adoption of e-banking practice.

\subsection{Problem Statement}

From the perspective of e-banking, researchers need to acknowledge the rationality behind the customer adoption in both developing and developed countries. In order to resolve this issue, several models and frameworks have been advanced by researchers in their studies such as Diffusion of Innovation (DOI), Theory of Reason Action (TRA), Social Cognitive Theory (SCT), Technology Acceptance Model (TAM), Unified Theory of Acceptance and use of Technology (UTAUT), Model of PC Utilisation, Motivational Model (MM), Theory of Interpersonal Behaviour, Theory of Planned Behaviour (TPB) and Compatible Unified Theory of Acceptance and use of Technology (C-UTAUT) [13], to enlighten the rationality supporting customer adoption. Nevertheless, the most dominantly utilised model is TAM model but lacks sufficient clarification on customer adoption, which may justify the failure for changes in customer's earlier experience [19]. As a result of this, the need for modification of TAM model and its adaptation are crucial in order to integrate certain prospective external factors that are in line with e-banking service unique characteristics that will effectively clarify the customer adoption of e-banking practice.

On the other hand, the accomplishment of any new technological service such as ebanking service cannot simply be subjected to its development but rather the adoption rate (i.e. the rate in which individuals will accept to use the service), thus considering the external variables of new technological service characteristics that prompt that adoption is imperative. [20] Supported this statement by adding that the acceptance or rejection of a new technological service by customers alongside the roots of circulation depends on the new technological service acceptance or rejection factors. This is why [9] suggested that any new technological product/service must be measured based on the observed characteristics in order to discover its association with the external variables. However, prior studies have conceptualized new technological service characteristics with relevant constructs such as relative advantage, innovation information, compatibility, image, observability, social approval, trialability, visibility and voluntariness among others [8 - 11]. Thus, the integration of these core determinants of new technological service characteristics with regards to ebanking practice will provide an insight on what motivates customer to adopt any given service.

Studies have shown the importance of innovation characteristics and the need for modification of TAM model but none have actually added these promising constructs under TAM extension model to enhance better insight on TAM extension model influence on customer adoption especially with regard to e-banking practice in Lagos state. Thus, this study suggests additional empirical study by extending TAM model to include few promising constructs of innovation characteristics to understand their influence on customer adoption of e-banking practices in Lagos state. To capture the extended model, four (4) determinants namely innovation relative advantage, innovation compatibility, innovation complexity and innovation information were incorporated to facilitate the extension TAM model. 


\subsection{Objectives of the Research}

The broad objective of this study is to examine the relationship between TAM extension model and customer adoption of e-banking practice in Lagos state; whereas the specific objectives are as detailed underneath;

i. To determine the relationship between innovation relative advantage (a dimension of TAM extension model) and customer adoption of e-banking practice in Lagos state.

ii. To identify the relationship between innovation complexity (a dimension of TAM extension model) and customer adoption of e-banking practice in Lagos state.

iii. To examine the relationship between innovation compatibility (a dimension of TAM extension model) and customer adoption of e-banking practice in Lagos state.

iv. To investigate the relationship between innovation information (a dimension of TAM extension model) and customer adoption of e-banking practice in Lagos state.

\subsection{Research Questions}

i. What is the relationship between innovation relative advantage (a dimension of TAM extension model) and customer adoption of e-banking practice in Lagos state?

ii. What is the relationship between innovation complexity (a dimension of TAM extension model) and customer adoption of e-banking practice in Lagos state?

iii. What is the relationship between innovation compatibility (a dimension of TAM extension model) and customer adoption of e-banking practice in Lagos state?

iv. What is the relationship between innovation information (a dimension of TAM extension model) and customer adoption of e-banking practice in Lagos state?

\subsection{Research Hypotheses}

The recommended hypotheses are below;

$\mathrm{H}_{01}$ : There is no significant relationship between innovation relative advantage (a dimension of TAM extension model) and customer adoption of e-banking practice in Lagos state.

$\mathrm{H}_{02}$ : There is no significant relationship between innovation complexity (a dimension of TAM extension model) and customer adoption of e-banking practice in Lagos state.

$\mathrm{H}_{03}$ : There is no significant relationship between innovation compatibility (a dimension of TAM extension model) and customer adoption of e-banking practice in Lagos state.

$\mathrm{H}_{04}$ : There is no significant relationship between innovation information (a dimension of TAM extension model) and customer adoption of e-banking practice in Lagos state.

\subsection{Literature Review}

\subsection{Theoretical Framework}

\section{TAM Extension Model Foundation}

The theoretical foundation of this study is TAM extension model and Innovation Diffusion Theory (IDT). TAM model is referred to as Technology Acceptance model, adapted from Theory of Reasoned Action (TRA) and evolved by Davis in 1989, in order to forecast the information system acceptance by customer. However, it has been established that only TAM model cannot give behavioural expectation/outstanding clarification [7] in addition, great success were not achieved by the researchers that utilized TAM model while positive outcomes were achieved from other determinants [21]. In this regard, researchers have concentrated on the TAM extension model and framework by including other constructs to improve descriptive capacity it required. The TAM extension model advocates that if a new 
technology is accessible to customers, their decision making on the usage depends on various internal and external characteristics. [17] Advanced TAM extension model (TAM 2) by combining cognitive instrumental processes (output quality, result demonstrability, perceived ease of use and job relevance) and social influence processes (image, voluntariness and subjective norm) in their framework. In the same way, [22] in their own view suggested TAM model extension by joining popular eight (8) model's components to form the Unified Theory of Acceptance and use of technology framework. [18] Added constructs like trust, perceived credibility and technology quality, accessibility of the system, convenience and quality of service as external constructs to examine the customers adoption and satisfaction in Nigerian e-banking practice. [23] Extended TAM model with trust and compatibility while [7] Incorporated social influence and perceived security.

\subsubsection{Innovation Diffusion Theory (IDT)}

The Innovation Diffusion theory was proposed by Rogers in 1962 in order to describe the circulation speed of new ideas and technology [8]. It affords an underpinning for understanding the adoption of innovation in addition to the elements that motivate the choice of prospective customer. [8] Opposed that diffusion is the act of communicating innovation to the individual in a population or social system. This circulation of innovation is affected by four main components namely; Innovation, communication medium, time and social system that deeply depends on human capital. [8] Also identified five innovation characteristics that influence the innovation adoption behavior. These innovation characteristics are relative advantage, complexity, compatibility, observability and trialibility however, the capability to determine the perception of customer on new technological features is believed to possess a considerable role in prediction its achievement in the retail outlet [9]. [20] Also agreed by stating that the sources of innovation circulation among customers and the motives behind whether to adopt or reject an innovation depends on the innovations factors. Thus, the theory supports the study because it suggests the developments and determinants of consumer predisposition sets which will assist in assessing the possibility of their new innovation success or failure.

\subsection{Conceptual Model}

The suggested conceptual model provides a strong theoretical insight to TAM extension model and customer e-banking adoption practice. This model builds upon core constructs in innovation characteristic with technology acceptance model in order to explain the appropriate constructs that bring about adoption of e-banking practice by customers. The suggested model is displayed overleaf.

Innovation relative advantage is the level at which the usage of a specific information communication technology is observed to be more advanced for task accomplishment than the earlier technologies usage [24]. In simple words, relative advantage is the rate at which customers have the confidence that the new technological service is more improved for task success than the former channel. However, [10] argued that there is no need to refer this concept as relative advantage since it is determined by hazards removal/social values/profitability/time saved. [8] And [20] suggested that if the observed innovation relative advantage is prominent, then the adoption by customer will increase [9]. Also added that innovation relative advantage is repeatedly referred to as the leading concept of adoption rate in the studies of adoption. 


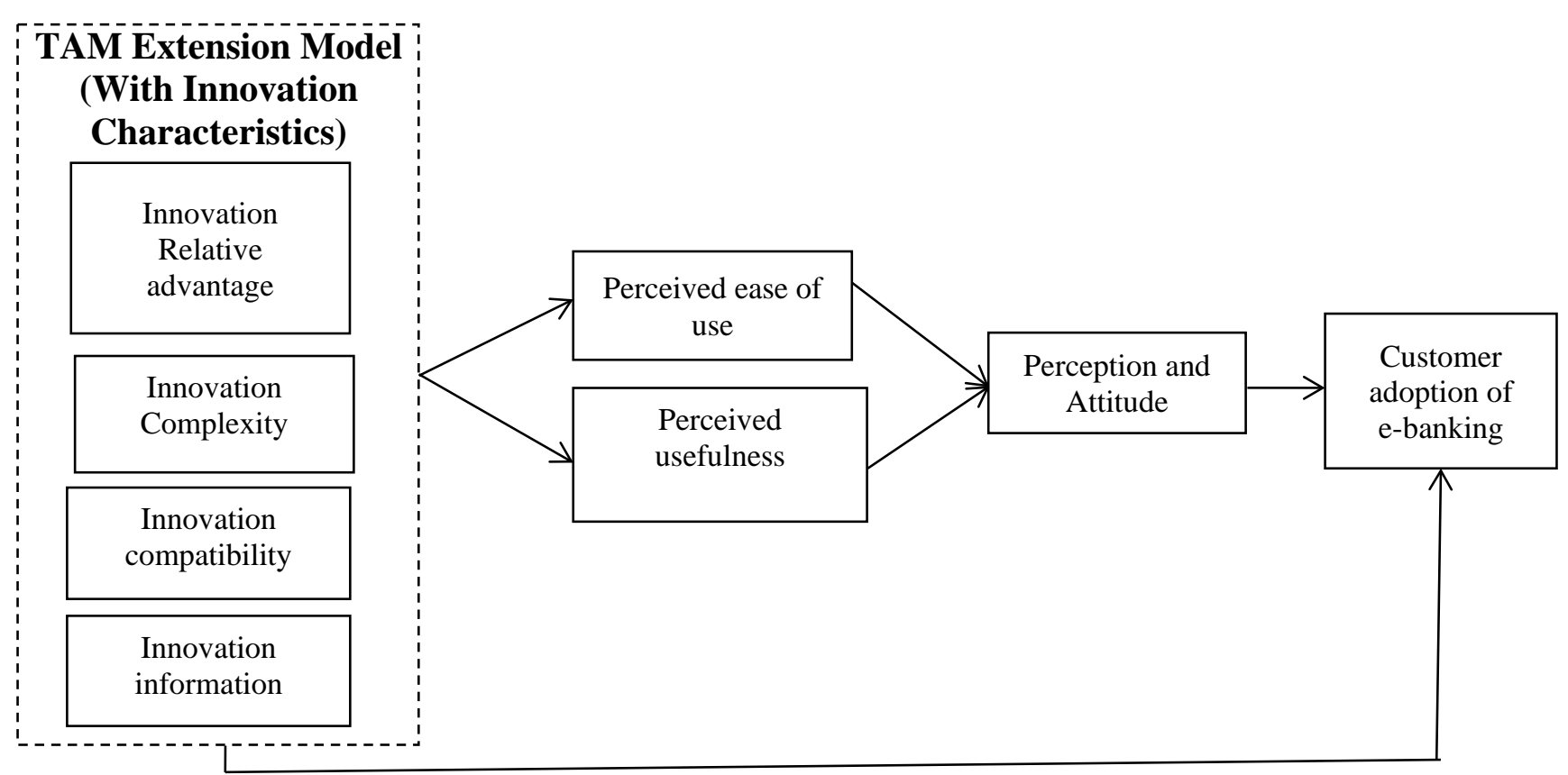

Source: Researchers suggested model (2021) from the reviewed literatures.

\section{Innovation Relative Advantage}

Relative advantage customers assumed all the benefits that an innovation can offer in using it, which may be measured through convenience, economic benefit, satisfaction, social position among others [20].

However, researchers results displayed that relative advantage and perceived usefulness are connected but the concepts are diverse [24]. Also, [11] Argued that Davis definition of perceived usefulness lack the use of word 'relative' in its name but it is in relative word. This supports that relative advantage has a significant relation with perceived usefulness and positively can donates to customer's attitudinal certainty. Thus, it is considered that a robust relative advantage will serve to influence perceived ease of use and perceived usefulness in direction of influencing positive perception and attitude towards the adoption of innovation in this case of e-banking practice.

\section{Innovation Complexity}

Innovation's complexity is described as the extent to which a new technological service is difficult to understand and use by customer [20,25]. Termed innovation complexity as the rate of effort in understanding innovations and customers observed ease of use. According to [9], innovation complexity can be subjected into two sub categories; complexity in use (innovation ease in which customers gain value) and design or technical complexity (innovation internal elements that generate usage value).

Looking at it from e-banking practice background, if customer understands that ebanking service is not simpler in usage, it will lower the adoption rate. Empirical study of [23] Has also indicated that system complexity directly influence perceived ease of use and perceived usefulness, which will affect customer's positive perception and attitude to accept e-banking practice $[2,18]$.

Thus, it is considered that a simpler innovation will serve to influence perceived ease of use and perceived usefulness in direction of influencing positive perception and attitude towards the adoption of innovation in this case of e-banking practice. 


\section{Innovation Compatibility}

Innovation compatibility seeks to determine the behavioural intentions of the customers in the direction of e-banking acceptance $[8,26]$. As cited in [11] observed that compatibility is the ability of a new technological service to be regular with prospective adopter's necessity, present attitude and previous encounter services. [25] Ascertained that compatibility is the extent to which newcomers (i.e potential customers) feels that the new technological service is capable of easy interaction with their want, earlier action and habits. Compatibility can also be seen as the level at which new technological service is observed to be in congruence with previous assumptions and prediction (values), needs and prior experience of prospective customers $[9,20]$. Viewed it as the appropriate manner to which new technological service suit customer's lifestyle (personal life) and components of social system (social structure). In other words, any defect from new technological service with prospective adopter's regularity will influence termination of usage. Other researchers have also found that compatibility has a significant influence on perceived ease of use and perceived usefulness $[25,27]$. Also agreed that compatibility has a substantial connection with perceived usefulness and perceived ease of use in online banking adoption. To be specific, concerning the perceived usefulness of system, customer prefers the connection of the system with their actions together with the provision of suitable condition and outcomes [23]. Thus, it is considered that a robust compatibility will serve to influence perceived ease of use and perceived usefulness in direction of influencing positive perception and attitude towards the adoption of innovation in this case of e-banking practice.

\section{Innovation Information}

Innovation information as advanced by [9] is a concept that handles intrinsic communication networks such as word of mouth and social networking; and extrinsic communication networks such as public relation and advertising in order to assist prospective customer with diverse advantages and usage information of the innovation. However, [9] Further added that innovation information is the derivative of communicability (the extent to which outcomes of innovation can be conveyed to others), observability (the extent in which the outcomes of a new technological are able to be seen by others) and trialabilty (the probability of taking possession of a new technological service as a trial before the concluding decision by customer). The concept of innovation information indicates that availability of information will assist the prospective customer with different benefits in order to defeat the undesirable outcomes that are linked to the innovation. Thus, it is considered that reference information will serve to influence perceived ease of use and perceived usefulness in direction of influencing positive perception and attitude towards the adoption of innovation in this case of e-banking practice.

\section{Customer Adoption}

In order to be able to promote products/service for adoption, it is essential to understand the adoption arrangement. [8] Noted that the adoption of a new technology is the customer's decision making to accept full usage of the technology. In the context of ebanking service, customer adoption can be seen as the personal decision of acceptance of ebanking service habitually. However, [8] also suggested that before customer can adopt any innovation, they must go through five (5) process; Knowledge (customers acquaintance of the existence of the innovation and being encouraged to get information), persuasion (customer deal with the accessible information that is linked with the innovation), decision (customer 
decides on whether to accept or reject the innovation), implementation (customer utilizes the innovation through a changing learning step), and confirmation (customer finalizes the decision to continue the usage of the innovation because of fulfillment with the innovation). [8] further acknowledged five taxonomy of adopters; innovators (individual that is eager to try the innovation); early adopters (individual that is comfortable with new innovation which appears valuable); early majority (individual that is slow-moving in acceptance of new technology but depends on recommendation from others); late majority (individual that are less eager to accept new ideas, technology or product but depends on others opinion that have tried and tested it); laggards (individual that tries product or service last after their preferred product or service is not available) [21]. Emphasized that e-banking adoption by customer depends on the stimuli that strongly recommend the adoption because it comprises of behaviour transformation. Thus, it is considered that positive adoption of innovation in the case of e-banking depends on relative advantage, complexity, compatibility and information that will serve to influence perceived ease of use and perceived usefulness in direction of influencing positive perception and attitude towards the adoption of innovation.

\subsection{Empirical Review}

Findings of past studies on TAM extension model and how it could impact on customer adoption of e-banking practice is clear both in developed and developing countries. [2] Explored the determinants that affect customer's level of acceptance and their e-banking intention usage in Nigeria. The modified TAM was utilized by adding self-efficacy of computer and perceived credibility to the foremost TAM model. However, the results discovered that the four (4) determinants (perceived usefulness, self-efficacy of computer, perceived credibility and perceived ease of use) affect the customer's level of acceptance and usage intention of e-banking in Nigeria. [23] Investigated the broadened TAM model application through addition of trust and compatibility to understand the adoption of online banking between Gulf region university students. Findings revealed that TAM constructs were confirmed and both trust and compatibility advances online banking adoption. [1] also looked at the affecting factors of e-banking adoption among Zambia banks customers by examining perceived usefulness, ease of use and trust elements (safety, credibility and security) effects on both attitude and adoption intention. Findings identified that extended TAM model is valid for bank customers in Zambia, also ease of use, trust and perceived usefulness positively influence attitude whereas attitude to e-banking affect adoption intention actual adoption of e-banking.

Assessed TAM [26] extension model along with innovation diffusion theory (IDT) and privacy/security risk on Greece's customer internet banking adoption. The outcomes of the analyses concluded that the service compatibility (main factor), TAM constructs (perceived usefulness and perceived ease of use), privacy/security risk have a positive influence on adoption of internet banking. Additionally, perceived usefulness and perceived ease of use as TAM's constructs, privacy/security risk mediates the link between compatibility and behavioural intention of customers whereas perceived usefulness mediates the link between perceived ease of use and customer's intentions. Lastly, in individual differences role on customers' beliefs towards internet banking, compatibility, value and risk elements, younger customers, mostly male customer with IT experience are a more favorable towards internet banking usage. Correspondingly, [25] investigated the prospective elements affecting student's behavioural intentions for usage of e-learning system in Malaysia through 
combination of TAM model and innovation diffusion theory (IDT). The result advocated that a modified TAM model and innovation diffusion theory (IDT) for the adoption of e-learning system usage enhanced student performance. The result also found that six (6) innovation characteristics influence the behavioural intention of e-learning student. Besides, perceived usefulness is greatly influenced by complexity, trialability, perceived enjoyment, observability, perceived compatibility and relative advantage.

\subsection{Methodology}

\subsection{Research Design}

The study utilized descriptive research design using cross-sectional survey method for data collection. The descriptive research design was regarded as a suitable design for the study because it completely describes the variables of the study without enfolding why it occurs.

\subsection{Study Population}

The aimed population was all operative customers of e-banking practice in Eti-Osa area in Lagos state that have account with a bank irrespective of their separate banks. EtiOsa is a local government area on the Island part of Lagos state in Nigeria and was preferred because the population is large enough for the study. As stated by the city population statistics map and chart, the entire population assessed was 390,800 individuals inside EtiOsa local government area as of 2016 since figures for recent years are not available. Thus, the total aimed population is 390,800 individuals.

\subsection{Sample Size and Selection}

With regard to this valuable sampling frame from the study population, the study employed [29] formula to establish the needed sample size. The formula is as indicated below:

$n=\frac{N}{1+N(e)^{2}}$

Where;

$\mathrm{n}$ - Needed sample size

$\mathrm{N}$ - Population under the study

e- Realistic sampling error

Hence;

$$
n=\frac{390,800}{1+390,800(0,05)^{2}}=399,59 \approx 400
$$

From the above calculation, the sample size is put at 400 for the study and obtained from the entire population employing convenience sampling method.

\subsection{Instrumentation}

The instrument used for the study was a structured questionnaire with closed-ended questions, distributed among the sample respondents. The questionnaire questions were in two sections ( $A$ and $B$ ); the section A comprises of the respondent's demographic information (comprising of five (5) items) whereas the section $B$ was developed to answer the research questions (comprising of twenty five (25) items). To be clear, in the evaluation of questions 
for TAM extension model, innovation relative advantage (comprises of five (5) items), innovation complexity (comprises of five (5) items), innovation compatibility (comprises of five (5) items) and innovation information (comprises of five (5) items), then the customer adoption with five (5) items. However, the Likert scale of five (5) points, varying appropriately from (1) - Strongly Disagree to (5) - Strongly Agree was used to obtain the respondents agreement on questions pertaining the variables under study.

\subsection{Pilot Study of the Instrument}

In an effort to ascertain the suitability of the instrument for the data collection, face and content validity were accomplished by giving the study instrument to three academic experts whilst their modifications were included in the final instrument. Then, a pilot study was done with 30 respondents from Eti-Osa local government area in an attempt to assess the reliability of the instrument using Cronbach alpha coefficient and the result displayed across the entire independent variables. The result is as displayed in table 1 below, indicating [28] satisfactory range of 0.7 and beyond.

Table 1

Study Reliability Test

\begin{tabular}{clcc}
\hline Sn & Study Variables & Items & Cronbach Alpha \\
\hline 1. & Innovation Relative Advantage & 5 & 0.799 \\
\hline 2. & Innovation Complexity & 5 & 0.777 \\
\hline 3. & Innovation Compatibility & 5 & 0.824 \\
\hline 4. & Innovation Information & 5 & 0.731 \\
\hline 5. & Customer Adoption & 5 & 0.778 \\
\hline
\end{tabular}

Source: Pilot Study, 2020

\subsection{Administration of the Instrument}

In order to enlighten the aim of the study and enhance the possibility of getting high response rate, the self-administered questionnaire was used by the researcher.

\subsection{Procedure for Analysis}

The study utilized both descriptive and inferential statistics such as Pearson Correlation and Multiple Regression to test the formulated hypotheses using statistical package for social science (SPSS-Version-21) in the process.

\subsection{Data Analysis \\ Test of Hypotheses}

The study outcomes were made known in agreement with the formulated null hypotheses of the influence of TAM extension model on customer adoption of e-banking practice.

$\mathrm{H}_{01}$ stated that there is no significant relationship between innovation relative advantage (a dimension of TAM extension model) and customer adoption of e-banking practice in Lagos state. However, finding revealed that innovation relative advantage has a significant correlation figure $(r)$ of $0.957^{* *}$ with customer adoption of e-banking practice. To this end, the result depicts a resilient, positive correlation between innovation relative advantage and customer adoption of e-banking practice in Lagos state. 
$\mathrm{H}_{02}$ stated that there is no significant relationship between innovation complexity (a dimension of TAM extension model) and customer adoption of e-banking practice in Lagos state.

Table 2

Correlational Matrix between dimensions of TAM extension model and customer adoption of e-banking practice in Lagos state

\begin{tabular}{|c|c|c|c|c|c|c|}
\hline \multicolumn{2}{|c|}{ SPSS Output } & CA & IRA & IC & INC & II \\
\hline \multirow{3}{*}{$\begin{array}{l}\text { Consumer } \\
\text { Adoption (CA) }\end{array}$} & $\begin{array}{l}\text { Pearson- } \\
\text { Correlation }\end{array}$ & 1 & & & & \\
\hline & Signif. (2 tailed) & & & & & \\
\hline & $\mathrm{N}$ & 394 & & & & \\
\hline \multirow{3}{*}{$\begin{array}{l}\text { Innovation } \\
\text { Relative } \\
\text { Advantage (IRA) }\end{array}$} & $\begin{array}{l}\text { Pearson- } \\
\text { Correlation }\end{array}$ & $.957^{* *}$ & 1 & & & \\
\hline & Signif. (2 tailed) & .000 & & & & \\
\hline & $\mathrm{N}$ & 394 & 394 & & & \\
\hline \multirow{3}{*}{$\begin{array}{l}\text { Innovation } \\
\text { Complexity (IC) }\end{array}$} & $\begin{array}{l}\text { Pearson- } \\
\text { Correlation }\end{array}$ & $.986^{* *}$ & $.965^{* *}$ & 1 & & \\
\hline & Signif. (2 tailed) & .000 & .000 & & & \\
\hline & $\mathrm{N}$ & 394 & 394 & 394 & & \\
\hline \multirow{3}{*}{$\begin{array}{l}\text { Innovation } \\
\text { Compatibility } \\
\text { (INC) }\end{array}$} & $\begin{array}{l}\text { Pearson- } \\
\text { Correlation }\end{array}$ & $.987^{* *}$ & $.965^{* *}$ & $.990^{* *}$ & 1 & \\
\hline & Signif. (2 tailed) & .000 & .000 & .000 & & \\
\hline & $\mathrm{N}$ & 394 & 394 & 394 & 394 & \\
\hline \multirow{3}{*}{$\begin{array}{l}\text { Innovation } \\
\text { Information (II) }\end{array}$} & $\begin{array}{l}\text { Pearson- } \\
\text { Correlation }\end{array}$ & $.894^{* *}$ & $.856^{* *}$ & $.873^{* *}$ & $.885^{* *}$ & 1 \\
\hline & Signif. (2 tailed) & .000 & .000 & .000 & .000 & \\
\hline & $\mathrm{N}$ & 394 & 394 & 394 & 394 & 394 \\
\hline
\end{tabular}

However, finding confirmed that innovation complexity has a significant correlation figure $(r)$ of $0.986^{* *}$ with customer adoption of e-banking practice. The result portrays a resilient, positive correlation between innovation complexity and customer adoption of ebanking practice in Lagos state.

$\mathrm{H}_{03}$ also stated that there is no significant relationship between innovation compatibility (a dimension of TAM extension model) and customer adoption of e-banking practice in Lagos state. However, finding confirmed that innovation compatibility has a significant correlation figure $(r)$ of $0.987^{* *}$ with customer adoption of e-banking practice. The result portrays a resilient, positive correlation between innovation compatibility and customer adoption of e-banking practice in Lagos state.

$\mathrm{H}_{04}$ affirmed that there is no significant relationship that exists between innovation information (a dimension of TAM extension model) and customer adoption of e-banking practice in Lagos state. However, data analysis confirmed that innovation information has a significant correlation ( $r$ ) of $\left.0.894^{* *}\right)$ with customer adoption of e-banking practice. The result portrays a resilient, positive correlation between innovation information and customer adoption of e-banking practice in Lagos state. 
Further analysis through the medium of multiple regression was carried out as indicated by the under stated regression equation to affirm the existence of association between the dimensions of TAM extension model and customer adoption of e-banking practice.

$Y=a+b_{1} x_{1}+b_{2} x_{2}+b_{3} x_{3}+b_{4} x_{4}+e$

The values of $b_{1}, b_{2}, b_{3}, b_{4}$ represents the coefficient of independent variables that is $x_{1}$ to $x_{4}$. $Y$ represents the dependent variable that is the customer adoption while alpha (a) represents regression constant.

$Y=-1.144+0.333 X_{1}+0.430 X_{2}+0.481 X_{3}+0.123 X_{4}+e$

$\mathrm{R}^{2}=0.981$

The equation suggests that there is a positive association between the independent variables and the dependent variable. This suggests that an increase in the value of each independent variable (relative advantage, complexity, compatibility and information) will lead to corresponding increase in the value of dependent variable (customer adoption). While the $\mathrm{R}^{2}$ indicate that the four (4) independent variables under study empirically explain $98 \%$ of the variation in the dependent variable. Thus, the table 3 and 4 overleaf displays the model summary and the coefficients output.

Table 3

Model Summary

\begin{tabular}{lccccc}
\hline R & \multicolumn{2}{l}{ Regression Relationship: } & & 0.990 \\
\hline RS & R-Squared: & & 0.981 \\
\hline ARS & Adjusted R-Square: & & 0.981 \\
\hline SEE & Standard Errors of the Estimate: & & 0.78453 \\
\hline \multicolumn{1}{r}{ ANOVA } & Sum of Squares & Degree of & Mean Square & F- & Significance. \\
& (SS) & Freedom (DF) & (MS) & Statistics & \\
\hline Regression & 12187.494 & 4 & 3046.873 & 4950.382 & $.000^{\text {b }}$ \\
Residual & 239.423 & 389 & .615 & & \\
Total & 12426.916 & 393 & & & \\
\hline
\end{tabular}

Note: Dependent Variable (DV) = Consumer Adoption

Independent variables (i.e. the dimensions of TAM extension model; are: Innovation Information

(II), Innovation Relative Advantage (IRA), Innovation Complexity (IC), Innovation Compatibility (INC)

Table 4

\section{Coefficients}

\begin{tabular}{llccccc}
\hline \multirow{2}{*}{ Model } & \multicolumn{2}{c}{$\begin{array}{c}\text { Unstandardized- } \\
\text { Coefficients }\end{array}$} & $\begin{array}{c}\text { Standardized- } \\
\text { Coefficients }\end{array}$ & T & Sig. \\
\cline { 2 - 5 } & \multicolumn{2}{c}{ B } & Std. Error & Beta $(\beta)$ & & \\
\hline \multirow{2}{*}{1} & -1.144 & .331 & & -3.455 & .001 \\
(Constant) & $\begin{array}{l}\text { Innovation Relative } \\
\text { Advantage (IRA }\end{array}$ & .333 & .039 & .342 & 7.002 & .000 \\
Innovation & & & & & \\
Complexity (IC) & .430 & .050 & .439 & 8.511 & .000 \\
\hline
\end{tabular}


Continuation Table 4

\begin{tabular}{|c|c|c|c|c|c|}
\hline $\begin{array}{l}\text { Innovation } \\
\text { Compatibility (INC) }\end{array}$ & .481 & .055 & .463 & 8.745 & .000 \\
\hline $\begin{array}{l}\text { Innovation } \\
\text { Information (II) }\end{array}$ & .123 & .018 & .101 & 6.695 & .000 \\
\hline
\end{tabular}

\subsection{Implication for the Innovator}

For any innovation to attract customer adoption such innovation must be endowed with attestable relative advantage, simplicity, match with customer's lifestyle and positive intrinsic (word of mouth and social networking) and extrinsic (public relation and advertising) communication networks for the whole process to succeed.

\subsection{Discussion of Findings}

Analyses recorded a significant relationship between innovation relative advantage and customer adoption of e-banking practice in Lagos state. This finding is in line with the argument of [8], who suggested that if the observed relative advantage is prominent, then the adoption by the customer will increase.

Similarly, analyses indicated a significant relationship between innovation complexity and customer adoption of e-banking practice in Lagos state. The finding is also in agreement with empirical study of [23] and [2] that expresses that system complexity directly influence perceived ease of use and perceived usefulness, which significantly influence customer's positive attitude to accept e-banking practice.

Equally, a significant relationship was recorded between innovation compatibility and customer adoption of e-banking practice in Lagos state. This finding is also in agreement with [23] finding that revealed that innovation compatibility advances online banking adoption.

Finally, there exist a positive relationship between innovation information and customer adoption of e-banking practice in Lagos state, a domain of the study. The finding is in agreement with [9] that pointed out that innovation information assists the prospective customer with different benefits in order to defeat the undesirable outcomes that are linked to the innovation.

\subsection{Conclusion and Recommendations}

The findings of this study may be sufficiently viewed to have revealed important and significant relationship between TAM extension model and e-banking adoption by customers in Lagos state, the domain of this study. The coefficient of determination further confirmed that the constructs built into the model importantly explained $98 \%$ of the variation in the adoption of e-banking service delivery to customers in Lagos state. This study importantly introduces a new concept in terms of innovation information (intrinsic and extrinsic information) to create a departure from previous studies.

Thus, the study recommends that an innovation will do very well if the innovation is made to capture all the variables investigated in this study to ensure rapid diffusion/adoption of the innovation for the whole process to be successful.

\subsection{Suggestions for Further Studies}

The study limitation can be a focus issue for future research. The study only examine e-banking practice as one without looking at various channels under e-banking practice such as telephone banking, automated teller machine (ATM), point of sale (POS), electronic fund 
transfer among others. Hence, future research can focus on TAM extension model effect on adoption rate in any channels of e-banking service.

\section{References}

1. Mwiya B., Chikumbi F., Shikapu C. Kabala E., Kaulung'ombe B., \& Siachinji B. (2017). Examining Factors Influencing E-Banking Adoption: Evidence from Bank Customers in Zambia. American Journal of Industrial and Business Management, 7, 741 - 759.

2. Adesina A.A., \& Ayo C. K. (2010). An Empirical Investigation of the level of User Acceptance of E-banking in Nigeria. Journal of Internet Banking and Commerce, 15(1), 1 - 13.

3. Owoseni O. O., \& Adeyeye T. C. (2014). An Empirical Assessment of Customers Intention Use Internet Banking in Nigeria. Research Journal of Finance and Accounting, 5(8), 40 - 46.

4. Altobishi T., Erboz G., \& Podruzsik S. (2018). E-Banking Effects on Customer Satisfaction: The Survey on Clients in Jordan Banking Sector. International Journal of Marketing Studies, 10(2), 151 - 161.

5. Ayo C. K., Adewoye J. O., \& Oni A. A. (2010). The State of E-banking in Nigeria: A Post-Consolidation Review. Journal of Emerging Trends in Economics and Management Sciences, 1(1), 37 - 45.

6. Tarhini A., Mgbemena C., Trab M., \& Masa-Deh A. (2015). User Adoption of Online Banking in Nigeria: A Qualitative Study. Journal of Internet Banking and Commerce, 20(3), 1 - 24.

7. Patel K. J., \& Patel H. J. (2018). Adoption of Internet Banking Services in Gujarat: An Extension of TAM with Perceived Security and Social Influence. International Journal of Bank Marketing, 36(1), 147 - 169.

8. Rogers E. M. (2003). Diffusion of innovations (5th Ed.). New York: Free Press.

9. Flight R., D'Souza G., \& Allaway A. W. (2011). Characteristics-Based Innovation Adoption: Scale and Model Validation. Journal of Product \& Brand Management, 20(5) $343-355$.

10. Tornatzky L.G.. \& Klein K.J. (1982). Innovation Characteristics and Innovation Adoption Implementation: A meta-analysis of findings. IEEE Transactions on Engineering Management, 28 - 45.

11. Moore G.C., \& Benbasat I. (1991). Development of an Instrument to Measure the Perceptions of Adopting an Information Technology Innovation. Information Systems Research, 2(3), 192 - 222.

12. Kapoor K., Dwivedi Y., \& Williams M. (2014). Conceptualising the Role of Innovation: Attributes for Examining Consumer Adoption of Mobile Innovations. The Marketing Review, 14(4), 405 - 428. http://dx.doi.org/10.1362/146934714X14185702841361

13. Taherdoost H. (2018). Development of an Adoption Model to Assess User Acceptance of E-Service Technology: E-Service Technology Acceptance Model. Behaviour \& Information Technology, 37(2), 173-197. https://doi.org/10.1080/014492 9X.2018.1427793

14. Davis F. D. (1989). Perceived Usefulness, Perceived Ease of Use, and User Acceptance of Information Technology. MIS quarterly, 13(3), 319 - 340.

15. Lai P. C. (2018). Security as an Extension to TAM Model: Consumers' Intention to Use a Single Platform EPayment. Asia-Pacific Journal of Management Research and Innovation, 13(3 - 4), 110 - 119.

16. El-Qirem A. I. (2013). Critical Factors Influencing E-Banking Service Adoption in Jordanian Commercial Banks: A Proposed Model. International Business Research, 6(3), 229 - 236.

17. Venkatesh V., \& Davis F. D. (2000). A Theoretical Extension of the Technology Acceptance Model: Four Longitudinal Field Studies. Management Science, 46(2), 186-204. https://doi.org/10.1287/ mnsc.46.2.186.11926.

18. Akinyemi I. O., Asani E. O., \& Adigun A. A. (2013). An Investigation of User's Acceptance and Satisfaction of E-banking System as a panacea towards a Cashless Economy in Nigeria. Journal of Emerging Trends in Computing and Information Sciences, 4(12), 954-963.

19. Agwu M .E, Atuma O., Ikpefan .O.A., \& Aigbiremolen M .O. (2014). Impediment of E-banking Services Marketing in Developing Economies. A Case Study of Nigerian Banks. European Journal of Business and Social Sciences, 3(3), 228-248.

20. Chang C., Liang C., \& Chiu Y. (2020). Direct or Indirect Effects from Perceived Characteristic of Innovation to Intention to Pay: Mediation of Continuance Intention to Use E-learning. Journal of Computer Education. 120. https://doi.org/10.1007/s40692-020-00165-6.

21. Kaur A., \& Malik. (2019). Examining Factors Influencing Indian Customers' Intentions and Adoption of Internet Banking: Extending TAM with Electronic Service Quality. Innovative Marketing, 15(2), 42 - 57.

22. Venkatesh V., Morris M. G., Davis G. B., \& Davis F. D. (2003). User Acceptance of Information Technology: Toward a unified view. MIS quarterly, 425 - 478. https://doi. org/10.2307/30036540. 
23. Sundarraj R. P., \& Manochehri N. (2011). Application of an Extended TAM Model for Online Banking Adoption: A Study at a Gulf-Region University. Information Resources Management Journal, 24(1), 1-13.

24. Wang Y., Darren B. M., \& Wang Y. (2011). Re-examining Relative Advantage and Perceived Usefulness: An Empirical Study. International Journal of Information and Communication Technology Education, 7(1), 46-59.

25. Al-Rahmi W. M., Yahaya N., Aldraiweesh A. A., Alamri M. M., Aljarboa N. A., Alturki U., \& Aljeraiwi A. A. (2019). Integrating Technology Acceptance Model with Innovation Diffusion Theory: An Empirical Investigation on Students' Intention to use ELearning Systems. IEEE Access, 7, 26797 - 26809.

26. Giovanis A. Binioris S., \& Polychronopoulos G. (2012). An Extension of TAM Model with IDT and Security/ Privacy Risk in the Adoption of Internet Banking Services in Greece. EuroMed Journal of Business, 7(1), $24-53$.

27. Raza, S.A., Umer, A. \& Shah, N. (2017). New Determinants of Ease of Use and Perceived Usefulness for Mobile Banking Adoption. International Journal of Electronic Customer Relationship Management, 11(1), 44 65.

28. Cooper D., \& Schindler, P. (2011). Business research methods. (11th Ed.). Boston, Massachusetts: McGraw Hill. 29. Yamane T. (1967). Statistics: An Introductory Analysis. ( $2^{\text {nd }}$ eds.). New York: Harper \& Row. 